\title{
SEDIMENTOLOGY OF AN OLIGOCENE-MIOCENE INCISED PALEOVALLEY, TYONEK FORMATION, COOK INLET BASIN, ALASKA
}

\author{
by \\ Emily S. Finzel ${ }^{1}$, Kenneth D. Ridgway ${ }^{1}$, and David L. LePain ${ }^{2}$
}

\section{INTRODUCTION}

The Cenozoic Cook Inlet basin is located in the forearc region of the Aleutian-Alaska Peninsula magmatic arc associated with subduction of the Pacific plate beneath the North American plate (fig. 1). A complicated stratigraphy, in part due to the fluvial nature of the depositional systems, was created in the basin by cycles of uplift, denudation, and accommodation related to subduction (Swenson, 1997). Cenozoic depositional systems filled the basin with sediment eroding locally from the exposed accretionary prism to the southeast and the active volcanic arc and southern Alaska Range to the northwest (Crick, 1971; Hartman and others, 1974; Hayes and others, 1976; Hite, 1976; Swenson, 1997). Axial fluvial systems deposited material in the Cook Inlet basin that was transported from eastern Alaska and possibly as far as western Canada (Kirschner and Lyon, 1973; Rawlinson, 1984). The Paleogene and Neogene section is up to 8,500 m thick, but thins dramatically toward the basin margins (Crick, 1971).

The term "Kenai Group" was first applied to the coal-bearing exposures around Cook Inlet (Dall and Harris, 1892). Subsequently, Paleogene and Neogene sedimentary rocks on the Kenai Peninsula were designated the Kenai Formation based on multiple measured sections onshore (Barnes and Cobb, 1959), and were later elevated to group status containing five formations based on subsurface type sections (Calderwood and Fackler, 1972). The Upper Oligocene-Lower Miocene Tyonek Formation is the focus of this study.

The Tyonek Formation (2,316 m) has been described in the subsurface type section in the Pan American No. 2 Tyonek State 17587 well (fig. 2) as fine- to coarse-grained massive sandstone and siltstone with coal beds up to $6.5 \mathrm{~m}$ thick (Crick, 1971). However, Tyonek outcrops (Magoon and others, 1976) examined in this study consist mostly of clast-supported angular conglomerate interbedded with pedogenic siltstone, fine- to medium-grained

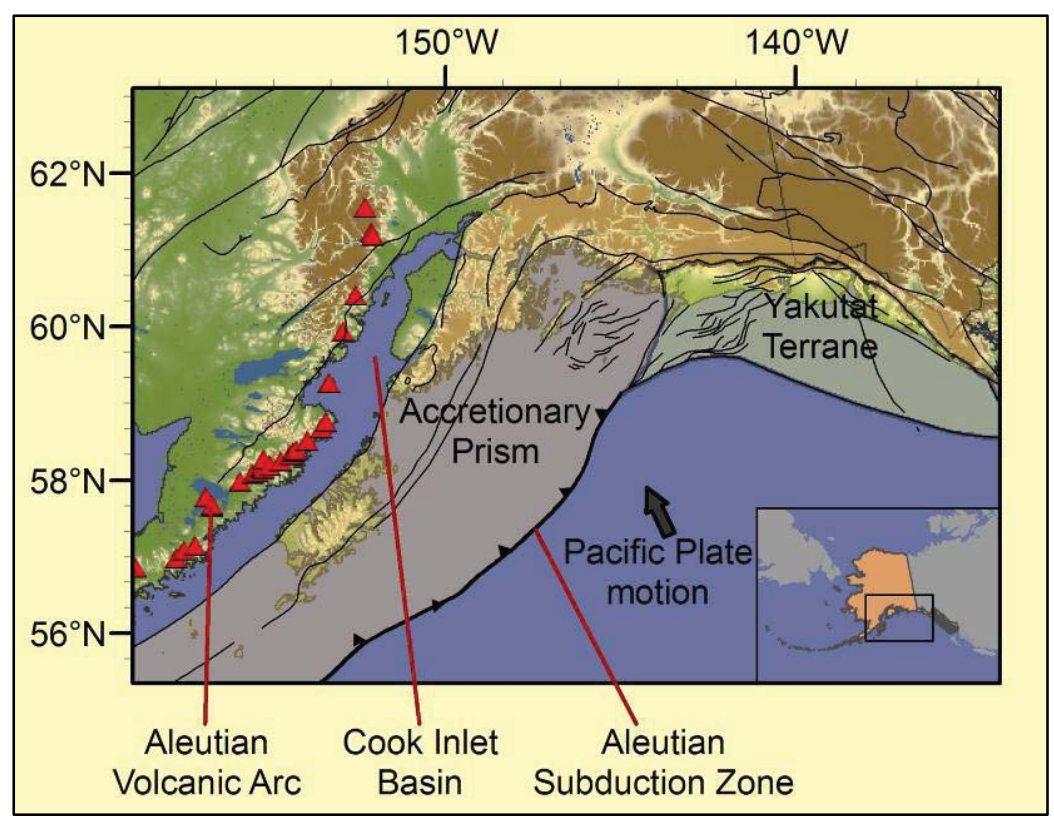

Figure 1. Tectonic map of the southern Alaskan plate margin showing the location of Cook Inlet basin and other important features of the convergent plate margin.

\footnotetext{
${ }^{1}$ Department of Earth and Atmospheric Sciences, Purdue University, West Lafayette, Indiana 47907; Emily Finzel - efinzel@purdue.edu ${ }^{2}$ Alaska Division of Geological \& Geophysical Surveys, 3354 College Rd., Fairbanks, Alaska 99709-3707
} 


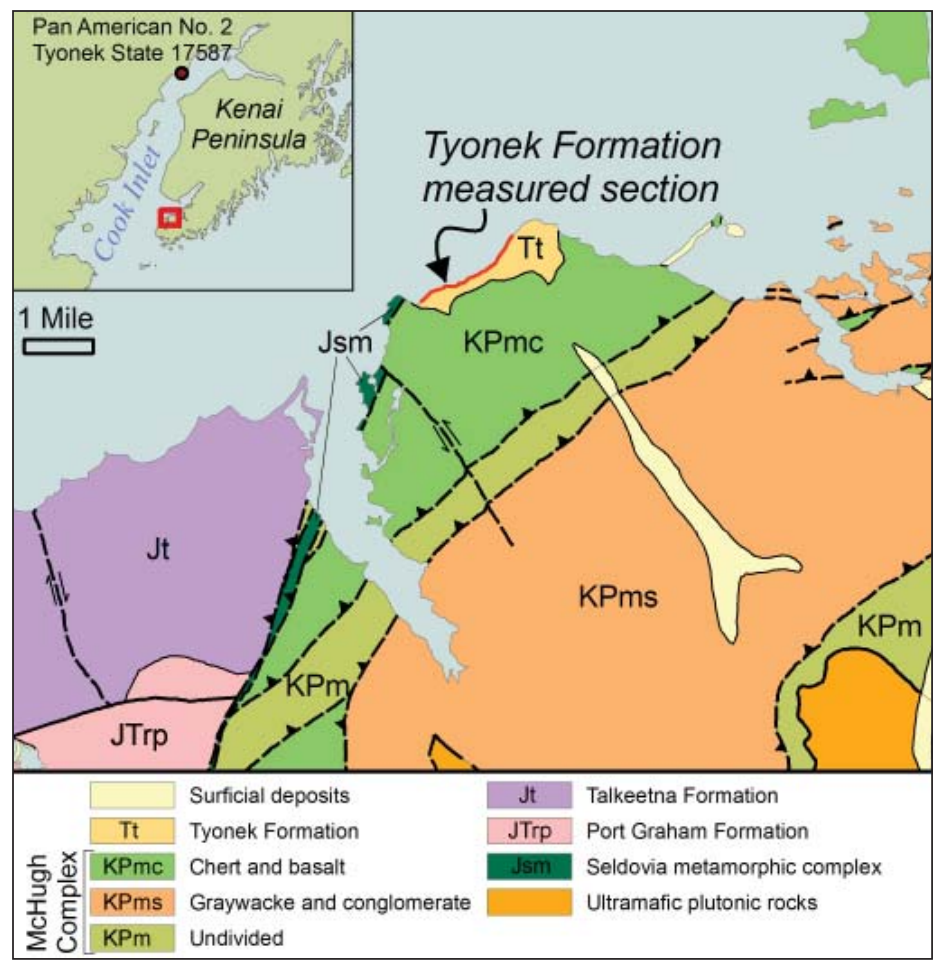

Figure 2. Geologic map of the Barabara Point area showing the location of the measured section (modified from Bradley and others, 1999).

massive and cross-stratified sandstone, and very minor coal. This may be a reflection of the different locations within the basin of the type section and measured section in this study. The section in this study is located near the basin margin; the type section probably reflects the character of the formation away from the basin margins.

\section{METHODS}

One stratigraphic section in the Tyonek Formation was measured near Homer (fig. 2). The lithology, texture, sedimentary structures, and fossil content of the strata were recorded. Samples from mudstone and siltstone were collected for x-ray diffraction (XRD) for compositional analysis and for palynological analysis to determine relative ages; sandstone samples were collected for provenance studies. All analyses are currently underway.

\section{SEDIMENTOLOGY}

The Tyonek Formation measured section is exposed on the southeast coast of Kachemak Bay near Barabara Point (fig. 2). The base of the Tyonek Formation there is unconformable and erosive into the underlying structurally deformed Triassic chert and greenstone. Strata of the gently north-northeast-dipping Tyonek Formation onlap onto the underlying units near the edges of the outcrop. This exposure is interpreted as part of the fill to an incised paleovalley. The lithofacies defined in table 1 have been divided into four facies associations listed in table 2 and described below.

Table 1. Summary of lithofacies.

\begin{tabular}{lll}
\hline Code & \multicolumn{1}{c}{ Description } & Geometry at outcrop scale \\
Gm & Massive, clast-supported conglomerate & Tabular and Lenticular \\
Gp & Planar cross-stratified clast-supported conglomerate & Tabular \\
Sm & Massive sandstone & Lenticular \\
Sh & Horizontally-stratified sandstone & Lenticular \\
Sp & Planar cross-stratified sandstone & Tabular \\
St & Trough cross-stratified sandstone & Tabular \\
Fsb & Angular, blocky siltstone & Tabular \\
Fsm & Massive siltstone & Tabular \\
\hline
\end{tabular}


Table 2. Summary of facies associations.

$\begin{array}{lll}\begin{array}{l}\text { Facies Association } \\ \text { Valley-margin ephemeral debris flows }\end{array} & \begin{array}{l}\text { Lithofacies } \\ \text { Gm, Fsb }\end{array} & \begin{array}{l}\text { Interpretation } \\ \text { Episodic debris flows interbedded with pedogenic } \\ \text { siltstone horizons near the margin of an incised valley } \\ \text { Valley-axis proximal braided streams } \\ \text { axis }\end{array} \\ \begin{array}{lll}\text { Sheet-flow braided stream deposits developed near the } \\ \text { Paludal environment }\end{array} & \text { Fsm, Fsm } & \begin{array}{l}\text { of an incised paleovalley } \\ \text { Isolated fluvial channels laterally adjacent to overbank } \\ \text { and marsh environments interbedded with crevasse } \\ \text { splay deposits }\end{array} \\ \text { Distal braided streams } & \text { St, Sp } & \text { Braided streams constructing a sandy braidplain }\end{array}$

\section{Facies Association 1: Valley-margin ephemeral debris flows}

Description. There are two primary lithofacies in this association: Massive, clast-supported conglomerate $(\mathrm{Gm})$ and massive siltstone (Fsb) (fig. 3). Facies $\mathrm{Gm}$ has dominantly very angular clasts with few sub-rounded types (fig. 4a). The clasts are mostly pebble- $(4-16 \mathrm{~mm})$ to cobble-sized $(1.6-25.6 \mathrm{~cm})$; the mean clast size is 2.9 $\mathrm{cm}$. Clast types identified in hand specimen include variously colored chert, minor quartz, and a predominance of greenstone and metasedimentary types. Individual beds of $\mathrm{Gm}$ average 1-2 $\mathrm{m}$ thick and thicken and thin laterally. Facies Gm frequently has erosive bases, some with very steep relief (fig. 4b). The lateral extent of beds of facies $\mathrm{Gm}$ is on the scale of $10 \mathrm{~m}$.

Facies Fsb is massive, mottled, or angular blocky. Slickensided, clay-lined surfaces, organic detritus, and rooted horizons are prevalent throughout this facies. Beds of Fsb average less than $0.5 \mathrm{~m}$ in thickness and are lenticular laterally. Thin lenses of conglomerate are found locally.

Interpretation. This facies association represents alternating periods of episodic debris flows (Gm) and relatively quiescent soil formation (Fsb) near the margins of an incised paleovalley. The angularity of the clasts suggests that they have not traveled far from their source, lending credence to proximity to a valley margin. Channel axes in this part of the section indicate a general paleoflow toward the northwest or southeast direction, but northwest-directed paleoflow is more reasonable considering the present high topography created by the growing accretionary prism to the southeast was interpreted to be present during deposition of this formation (Magoon and Egbert, 1986). Upright trees appear to be progressively buried by distinct, relatively low energy sedimentation events. Steep, erosive surfaces cut by facies Gm into underlying deposits of Fsm suggest that facies Fsb had been exposed for a long enough period of time to become cohesive (fig. 4d). Mottled textures in facies Fsb are the product of root systems that churn the soil and destroy bedding. Angular, blocky textures result from the swelling and shrinking of the sediments upon wetting and drying (Retallack, 1997). Stress cutans are surfaces that are formed by compressively orienting the clays in the sediments due to swelling, and often display slickensided surfaces as a result (fig. 4c; Bridge, 2003).

\section{Facies Association 2: Valley-axis braided streams}

Description. This facies association consists of five lithofacies present in varying abundance: Massive, clastsupported conglomerate (Gm), planar cross-stratified conglomerate (Gp), horizontally-stratified sandstone (Sh), massive sandstone (Sm), and massive siltstone (Fsm) (fig. 3). Facies Gm is most common at the base of the association, has tabular geometries at the outcrop scale (fig. 5a), and is normally graded and contains imbricated clasts. The cobble-sized clasts are sub-rounded to well rounded (fig. 5b), and generally grain size decreases upsection. The mean clast size near the base of facies association 2 is $7.2 \mathrm{~cm}$, and near the middle and top of the association is $4.4 \mathrm{~cm}$ and $4.3 \mathrm{~cm}$, respectively. Minor interbeds of medium-grained horizontally-stratified sandstone (Sh) occur within facies $\mathrm{Gm}$.

Planar cross-stratified conglomerate (Gp) occurs mostly at the base of the association, and bedding is tabular at the scale of the outcrop and has similar clast characteristics to facies Gm. Facies Sm is medium-grained and typically lenticular over several meters. Facies Fsm is tabular at outcrop scale and contains minor leaf fossils and coaly horizons. Average bed thickness is 1-2 m but beds thicken and thin laterally.

Interpretation. Clasts that are rounded, in combination with normal grading in facies Gm, clast imbrication, and the presence of facies Gp and Sh all suggest tractive transportation of sediment in a fluvial setting (Miall, 2000). 


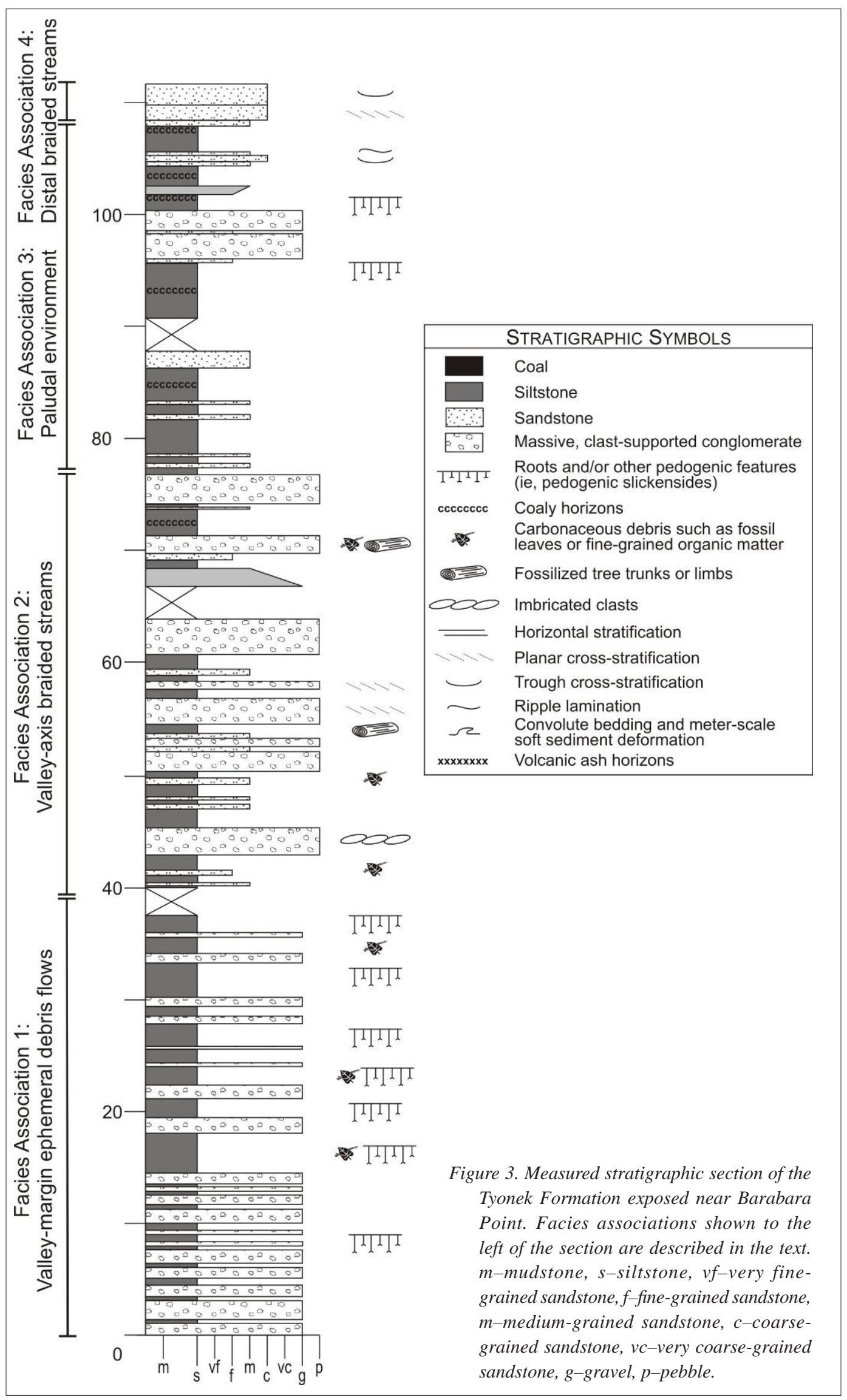




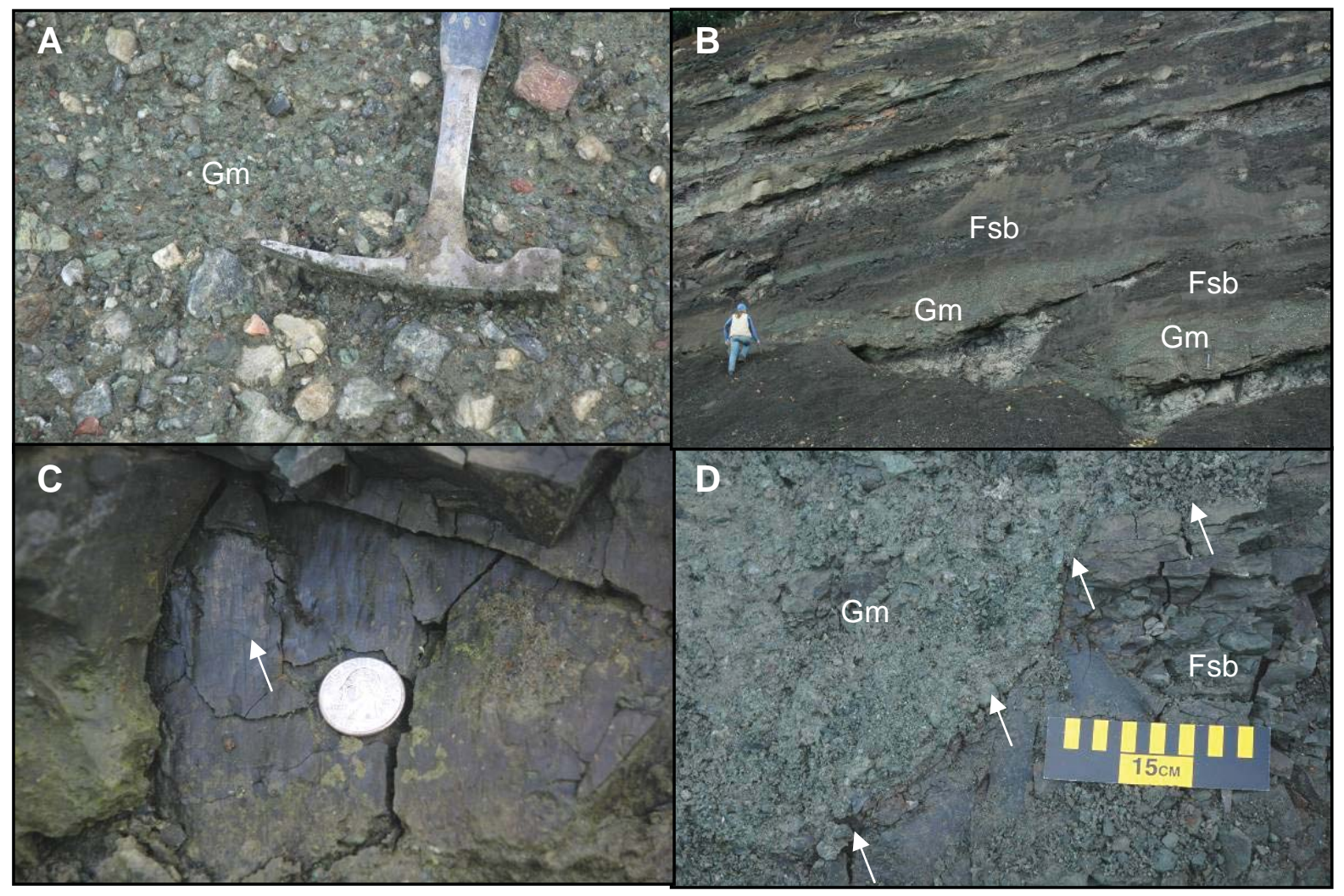

Figure 4. Photographs from facies association 1 valley-margin ephemeral debris-flow deposits. A. Angular clasts dominate the massive conglomerate (Gm) near the base of the section; B. The massive conglomerate (Gm) and siltstone (Fsb) display lenticular geometries in this part of the section; C. Pedogenic features such as stress cutan surfaces with slickensides are common in the siltstone (Fsb); D. The massive conglomerate $(\mathrm{Gm})$ forms steep, erosive cuts into underlying siltstone (Fsb).

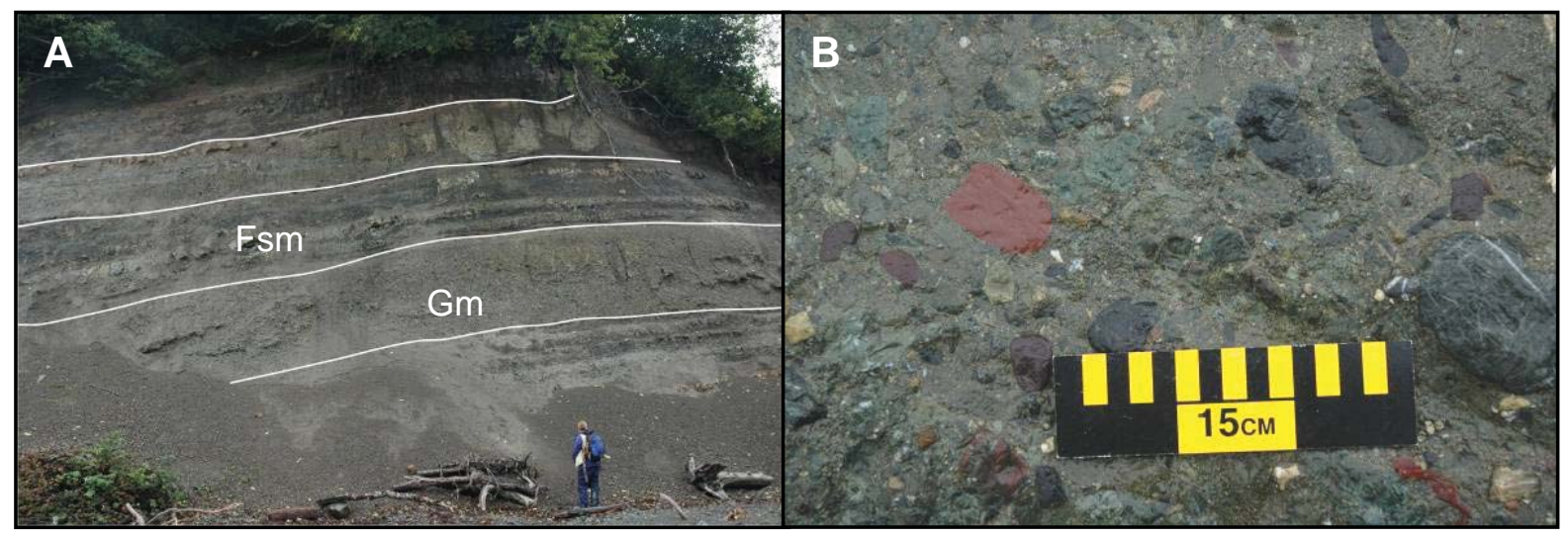

Figure 5. Photographs from facies association 2 valley-axis braided stream deposits. A. The massive clast-supported conglomerate $(\mathrm{Gm})$ has tabular geometries in this part of the section; B. Sub-rounded to rounded clasts of chert, quartz, greenstone, and metasedimentary types dominate the massive conglomerate $(\mathrm{Gm})$ in this part of the section 
The tabular nature of the conglomerate beds implies sheet-like flow similar to that in modern braided systems. Imbricated clasts suggest a paleoflow direction toward the west. The overall upsection reduction in mean clast size suggests that the system is losing transport capacity as it grades into facies association 3 . This facies association is interpreted as braided stream deposits that occupy the axis of a paleovalley.

\section{Facies Association 3: Paludal environment}

Description. The two main lithofacies in this association are massive siltstone (Fsm) and massive sandstone (Sm) (fig. 3). Facies Fsm is the dominant lithofacies but the majority of it is poorly exposed due to slumping and weathering (fig. 6). It is tabular at the scale of the outcrop and trenching revealed several rooted and coaly horizons. A few beds grade from gray siltstone to red clayey siltstone to a rooted surface.

Facies Sm consists of lenticular bodies of massively-bedded fine-grained sandstone that thicken and thin laterally with thicknesses from about 5 to $20 \mathrm{~cm}$. The sandstone is gray to green and appears rich in dark micas in hand specimen. One 4-m-thick bed of lithofacies Gm is present (96 m on fig. 3); clasts within are sub-rounded to well rounded and have a mean clast size of $2.9 \mathrm{~cm}$.

Interpretation. Thick packages of facies Fsm indicate a very low energy depositional environment. Siltstones that grade upward to clayey and rooted horizons may indicate a strongly-developed soil horizon with exposure on the order of 100,000 years (Bridge, 2003). These packages, as well as other rooted and coaly horizons, suggest deposition in overbank and swamp environments. Facies Sm may be the result of floods when laterally adjacent rivers overstepped their banks and deposited coarser material on the surrounding floodplain. The presence of facies Gm indicates minor fluvial channels.

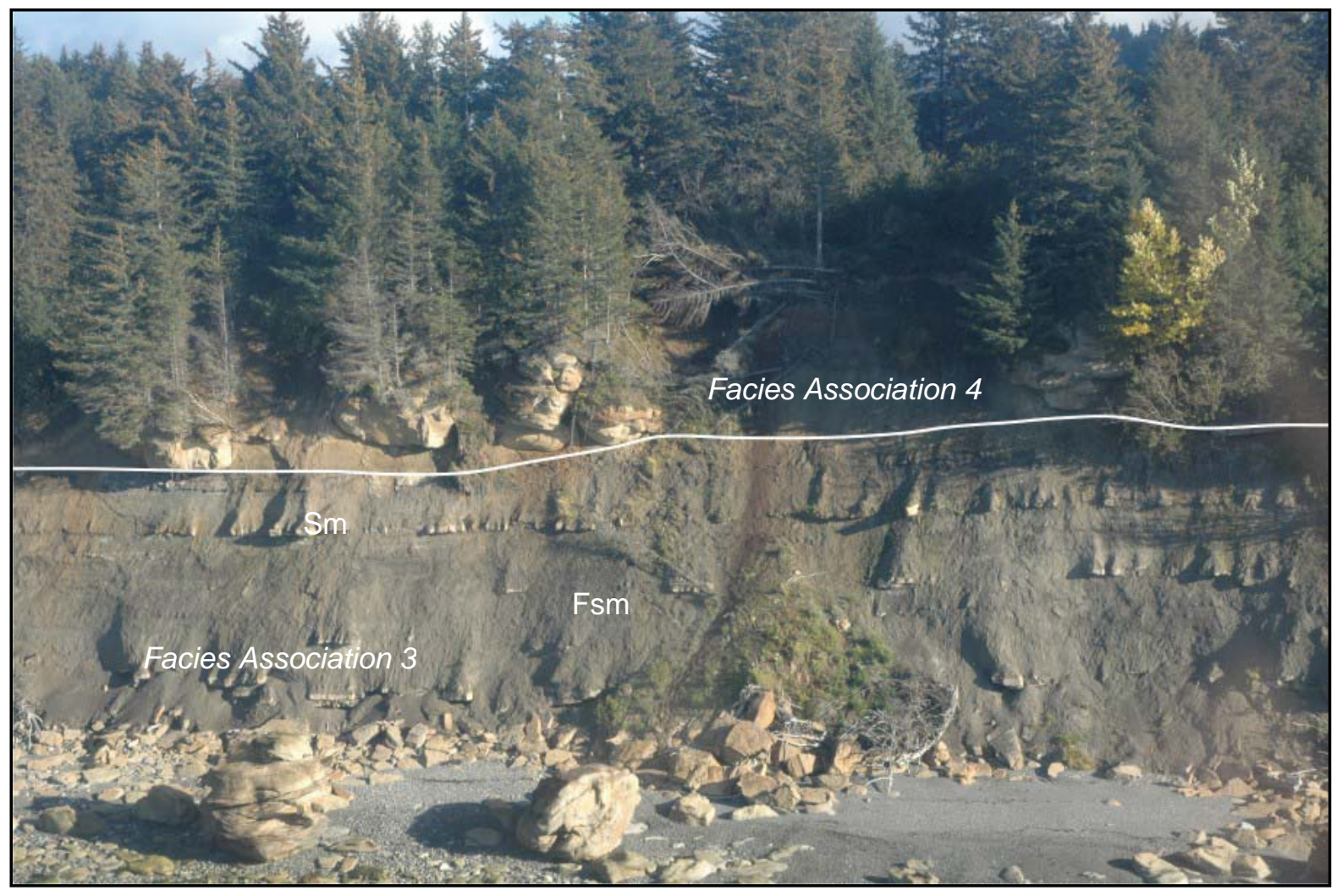

Figure 6. Aerial field photograph from the top part of the measured section showing facies associations 3 and 4 . Weathering of the dominant siltstone facies (Fsm) causes poor exposure in the paludal deposits of facies association 3. Massive sandstone $(\mathrm{Sm})$ forms thin, tabular bodies in this part of the section. Note the thick, light-colored sandstone of facies association 4 exposed at the top of the section. Facies association 4 can be traced to the southeast (right) along most of the top of the 0.3-km-long outcrop. 


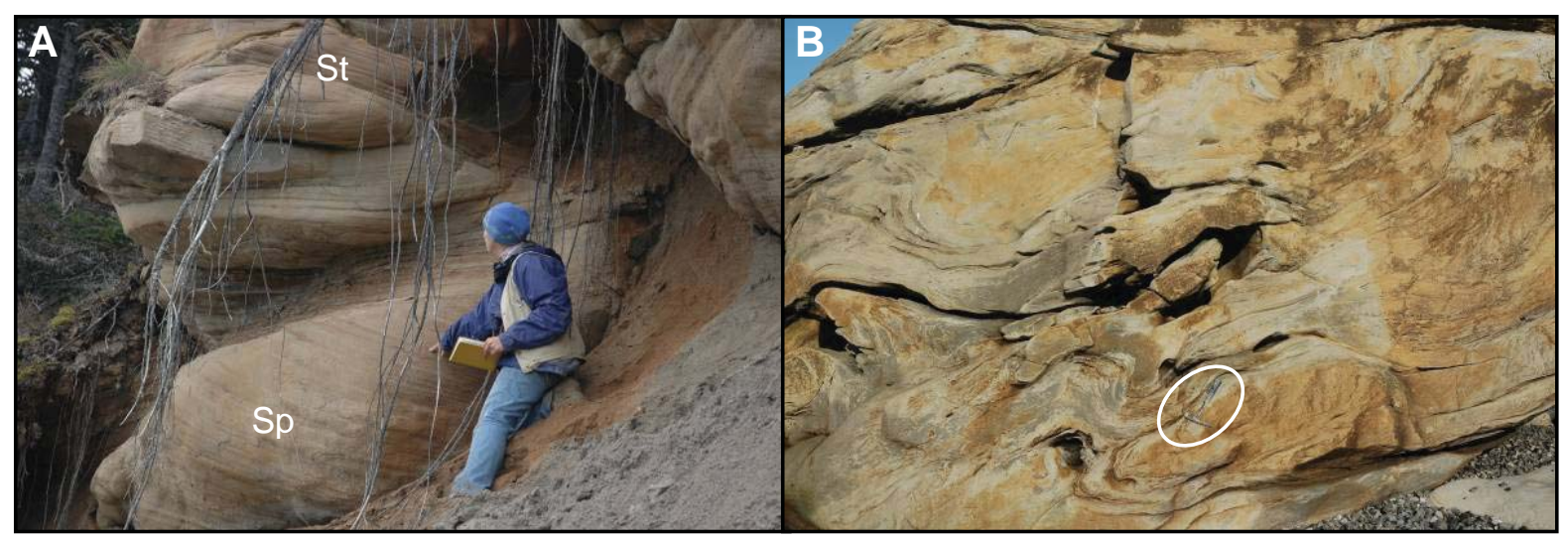

Figure 7. Photographs from facies association 4 distal sandy braided deposits. A. Facies association 4 consists of thick beds of trough cross-stratified (St) and planar cross-stratified (Sp) sandstone; B. Several-meter-scale soft-sediment deformation is common in this association. Hammer in circle for scale.

\section{Facies Association 4: Distal braided streams}

Description. Facies association 4 consists of two lithofacies: trough (St) and planar (Sp) cross-stratified sandstone (fig. 3). This unit is laterally extensive and could be traced across the top of nearly the entire 0.3-km-long exposure (fig. 6). Beds in this facies are 30-40 cm thick on average, but can reach up to $1 \mathrm{~m}$ thick (fig. 7a). Foreset thickness ranges from 5-10 $\mathrm{cm}$ in some of the thicker beds and 1-2 cm in the thinner beds. Large, soft sediment deformation structures deform entire beds on the scale of over a meter (fig. 7b). Organic debris occurs on foresets and bedding planes. The sandstone is dark to light tan and appears rich in white mica in hand specimen.

Interpretation. Facies association 4 may represent deposition in a distal fluvial environment. The sheet-like geometry of the deposit and the evidence of tractive transport (i.e., cross-stratification) suggest deposition on a sandy braid plain. Paleoflow directions measured from facies Sp and St suggest a southerly direction. The composition of this facies looks very different in hand sample from sandstone or conglomerate compositions in the underlying associations, which could indicate a different provenance for this unit. The large-scale convolute bedding may be a sign of tectonic activity, such as subduction-related earthquakes, during deposition.

\section{PRELIMINARY CONCLUSIONS}

The Tyonek Formation exposure on the eastern coast of Kachemak Bay is interpreted as part of the fill to an incised paleovalley. Where exposed in this area, the base of the Tyonek Formation is unconformable and erosive into the underlying structurally deformed Triassic chert and greenstone. Strata of the gently north-northeast-dipping Tyonek Formation onlap onto the underlying units at the margins of the outcrop and fill a present-day topographic low adjacent to the Triassic chert and greenstone.

Facies association 1, consisting of ephemeral debris-flow deposits and pedogenic siltstone, occurs at the base of the inferred paleovalley (fig. 7). This association represents a period when episodic high-energy sedimentation punctuated a primarily low-energy environment. This environment experienced enough subaerial exposure temporally to develop soil characteristics in the siltstone (Fsb), such as stress cutans, and to become cohesive enough that steep erosive surfaces were cut down into these deposits by conglomeratic debris flows (Gm).

Facies association 2 represents the next stage in the paleovalley, when proximal braided streams dominated the system, producing massive (Gm) and planar cross-stratified (Gp) conglomerate (fig. 7). Overbank and floodplain facies are represented by the massive siltstone (Fsm), massive sandstone ( $\mathrm{Sm}$ ), and horizontally-stratified sandstone $(\mathrm{Sh})$ interbeds. Facies association 2 grades upsection to the paludal environment defined by facies association 3 (fig. 7). This marsh and floodplain environment is characterized by thick units of massive siltstone (Fsm) and thin, tabular units of massive sandstone (Sm). Facies Sm may represent crevasse splay deposits associated with isolated fluvial channels represented by lenticular bodies of massive conglomerate (Gm).

Facies association 4 is anomalous in terms of its apparent provenance, lateral extent, and bedforms. Qualitative inspection of hand specimens reveals a mica-rich composition dissimilar to the greenstone- and chert-rich lithologies of the other associations. The lateral extent of facies association 4 is much greater than the others; it extends across the top of the entire exposure and is traceable for more than $0.5 \mathrm{~km}$ before eroding off to the south 
or diving into the subsurface to the north. Thick units of trough and planar cross-stratified sandstone are unique compared to the other conglomerate- and siltstone-dominated facies associations.

The development of a paleovalley during the Late Oligocene-Early Miocene may indicate uplift in the adjacent accretionary prism at that time. Tectonic uplift of the basin margin would lead to incision of streams as relative base level drops and the river systems attempt to maintain their gradient (Bridge, 2003). Uplift of the accretionary prism would also provide a source for sediments deposited in the paleovalley; the predominance of greenstone, chert, and quartz are suitable lithologies that may have been derived from the accretionary prism. If the paleovalley extends into the offshore subsurface, stratigraphic traps commonly associated with such depositional features may exist.

\section{FUTURE WORK}

A major question related to all the Tertiary depositional systems in the Cook Inlet forearc basin is what the provenance for each unit is and how it changes in time and space. For example, can we see a difference in provenance between the axial and marginal fluvial systems? One way to test this is through the use of detrital zircons. Individual zircon grains will be separated from bulk samples collected from the Tyonek, Beluga, and Sterling formations. Ages for each zircon grain will be acquired through LA-MC-ICPMS (Laser Ablation-Multiple-Collection-Inductively Coupled Plasma Mass Spectrometry) U-Th-Pb geochronological analyses. These ages will be compared to published ages obtained from all around southern Alaska in an effort to determine the provenance for each formation. This will also allow a more detailed reconstruction of the depositional systems. Key sediment source areas to focus on will include the Aleutian-Alaska Peninsula volcanic arc, the Alaska Range, the Talkeetna volcanic arc, and the Chugach Mountains (accretionary prism).

In the Seldovia area, this method can be used to analyze the provenance between the unique sandstone observed at the top of the Tyonek section (facies association 4) and that of the underlying strata. Rotation of paleocurrent directions from west- to south-directed from the base to the top of the section, as well as the different sedimentological character and the qualitative discrepancy in provenance, all suggest that the sediment sources for this part of the Tyonek may have changed as it was deposited.

\section{ACKNOWLEDGMENTS}

Field operations for the September 2006 field season were funded by the Alaska Division of Geological \& Geophysical Surveys (DGGS) operating budget. We thank Bob Gillis of DGGS for his helpful review of our manuscript.

\section{REFERENCES}

Barnes, F.F., and Cobb, E.H., 1959, Geology and coal resources of the Homer district, Kenai coal field, Alaska: U.S. Geological Survey Bulletin 1058-F, p. 217-260, 11 sheets, scale 1:2,400.

Bradley, D.C., Kusky, T.M., Haeussler, P.J., Karl, S.M., and Donley, D.T., 1999, Geologic map of the Seldovia quadrangle, south-central Alaska: U.S. Geological Survey Open File Report 99-18, http://pubs.usgs.gov/ of/1999/of99-018/.

Bridge, J.S., 2003, Rivers and floodplains: forms, processes, and sedimentary record: Oxford, U.K., Blackwell Publishing, $491 \mathrm{p}$.

Calderwood, K.W., and Fackler, W.C., 1972, Proposed stratigraphic nomenclature for the Kenai Group, Cook Inlet basin, Alaska: American Association of Petroleum Geologists Bulletin, v. 56, no. 4, p. 739-754.

Crick, R.W., 1971, Potential petroleum reserves, Cook Inlet, Alaska in Cram, I.H., ed., Future petroleum provinces of the United States - their geology and potential: American Association of Petroleum Geologists Memoir, v. 15, no. 1, p. 109-119.

Dall, W.H., and Harris, G.D., 1892, Correlation papers-Neocene: U.S. Geological Survey Bulletin 84, p. 234-238.

Hartman, D.C., Pessel, G.H., and McGee, D.L., 1974, Stratigraphy of the Kenai Group, Cook Inlet: Alaska Division of Geological \& Geophysical Surveys, Alaska Open File Report 49, 7 p., 11 sheets, scale 1:500,000.

Hayes, J.B., Harms, J.C., and Wilson, T.W., 1976, Contrasts between braided and meandering stream deposits, Beluga and Sterling formations (Tertiary), Cook Inlet, Alaska in Miller, T.P., ed., Recent and ancient sedimentary environments in Alaska: Anchorage, Alaska, Alaska Geological Society Symposium Proceedings, p. J1-J27.

Hite, D.M., 1976, Some sedimentary aspects of the Kenai Group, Cook Inlet, Alaska in Miller, T.P., ed., Recent and ancient sedimentary environments in Alaska: Anchorage, Alaska, Alaska Geological Society Symposium Proceedings, p. I1-I22. 
Kirschner, C.E. and Lyon, C.A., 1973, Stratigraphic and tectonic development of the Cook Inlet petroleum province in Pitcher, M.G., ed., Arctic geology: American Association of Petroleum Geologists Memoir, no. 19, p. 396-407.

Magoon, L.B., Adkison, W.L., and Egbert, R.M., 1976, Map showing geology, wildcat wells, Tertiary plant fossil localities, K-Ar age dates, and petroleum operations, Cook Inlet area, Alaska: U.S. Geological Survey Miscellaneous Investigations 1019, 3 sheets, scale 1:250,000.

Magoon, L.B. and Egbert, R.M., 1986, Framework geology and sandstone composition in Magoon, L.B., ed., Geologic Studies of the Lower Cook Inlet COST No. 1 well, Alaska Outer Continental Shelf: U.S. Geological Survey Bulletin 1596, p. 65-90.

Miall, A.D., 1996, The geology of fluvial deposits; sedimentary facies, basin analysis, and petroleum geology: Berlin, Germany, Springer-Verlag, 582 p.

Rawlinson, S.E., 1984, Environments of deposition, paleocurrents, and provenance of Tertiary deposits along Kachemak Bay, Kenai Peninsula, Alaska: Sedimentary Geology, no. 38, v. 1-4, p. 421-442.

Retallack, G.J., 1997, A colour guide to paleosols: Chichester, United Kingdom, John Wiley \& Sons, 170 p.

Swenson, R.F., 1997, Introduction to Tertiary tectonics and sedimentation in the Cook Inlet Basin in Karl, S.M., Vaughn, N.R., and Ryherd, T.J., eds., 1997 Guide to the geology of the Kenai Peninsula, Alaska: Anchorage, Alaska, Geological Society of Alaska, p. 18-27. 